\title{
The Use of Video Materials for the Development of Inner Motivation in Learning Foreign Languages of University Students
}

\author{
Viktoriya Vladislavovna Vetrinskaya ${ }^{1, *}$, Nataliia Vladimirovna Poliakova ${ }^{2}$, \\ Veronika Petrovna Shabanova ${ }^{3}$

\begin{abstract}
${ }^{1}$ Department of Foreign Languages, Peoples’ Friendship University of Russia (RUDN University), Moscow, Russian Federation
${ }^{2}$ Department of Romance Philology, Moscow Region State University, Moscow, Russian Federation

${ }^{3}$ Faculty of Romance and Germanic Languages, Moscow Region State University, Moscow, Russian Federation
\end{abstract}

Received September 16, 2020; Revised October 23, 2020; Accepted November 29, 2020

\section{Cite This Paper in the following Citation Styles}

(a): [1] Viktoriya Vladislavovna Vetrinskaya, Nataliia Vladimirovna Poliakova, Veronika Petrovna Shabanova , "Evaluation of a Developed Intelligent Tutor System for Learning Robotic Programming Course in Tertiary Institutions South East, Nigeria," Universal Journal of Educational Research, Vol. 8, No. 12, pp. 7101 - 7108, 2020. DOI: 10.13189/ujer.2020.081277.

(b): Viktoriya Vladislavovna Vetrinskaya, Nataliia Vladimirovna Poliakova, Veronika Petrovna Shabanova (2020). Evaluation of a Developed Intelligent Tutor System for Learning Robotic Programming Course in Tertiary Institutions South East, Nigeria. Universal Journal of Educational Research, 8(12), 7101 - 7108. DOI: 10.13189/ujer.2020.081277.

Copyright $@ 2020$ by authors, all rights reserved. Authors agree that this article remains permanently open access under the terms of the Creative Commons Attribution License 4.0 International License

\begin{abstract}
Our research aims to distinguish the types of motivation that are especially significant for undergraduate students and how authentic video materials foster the development of these types of motivation. Sample for the research was 67 undergraduate students from two Moscow universities - from MRSU (31 students) and from RUDN (36 students). The experiment was carried out in the autumn term of the 2019-2020 academic year. In the course of the research, a survey of students was conducted to identify the most significant factors contributing to an increase in the motivation of learning activities. According to the results of the survey, for senior undergraduate students, the opportunity to plan their learning activities independently acquires the greatest value. The creation of a favourable emotional environment in the classroom and adequate assessment of students are important but not determining factors in the development of motivation. The implementation of innovative pedagogical technologies and psychological and pedagogical support of the learning process are equally important for the formation of motivation. As part of the study, authentic professional video materials were selected and techniques for working with them were developed. The developed materials can be used for teaching language for specific purposes in the areas of Pedagogy, Economics, and Management. Students
\end{abstract}

note that the use of the foreign language being studied in real situations of professional communication is the leading motivational factor. The participation of students in the film making process encourages the development of social and communicative competencies, prepares them for future professional activity.

Keywords Professional Education, Methodology of Teaching a Foreign Language, Motivation, Authentic Video Materials

\section{Introduction}

It is possible to consider the formation, development, and support of learning activity motivation as one of the most significant issues in pedagogy. Despite the fact that this problem starts to be dealt with the early stage of education, the given task remains relevant in higher education. Currently, the concept of "lifelong learning" is becoming increasingly important. The use of modern teaching methods and techniques, the development of creative thinking and students' motivation play an important role in the implementation of this concept. 
Problems of motivation in the course of the learning process have been analysed in some research. For example, C. Kobylinski and M. Heinz related the implementation of motivation strategies and students' performance when the object of the study was skills acquisition by foreign students who were learning the language of the educational process [1].

When studying motivation, some researchers pay attention to the importance of the increase in the number of innovations dedicated to implementation of new technological tools (software) which make it possible to enhance pedagogical opportunities of mathematical disciplines teaching [2, 3]. Scientists highlight the fact that conventional teaching decreases motivation of students, who become more inactive as compared to the teaching using IC technologies.

There are numerous publications that are devoted to the extent of influence of IC technologies used in the educational process on motivation and keeping it on the same level by students [4].

In her article Marie Elomba Adebiyi presents aspects of students' motivation which take into consideration the interrelation between students' values and their academic goals. The author's study shows that values connected with academic goals and learning results correlate slightly but positively with students' educational processes [5].

Leading teachers and methodologists devote their publications to the problem of the formation and development of motivation necessary for the performance of learning activity. Thus, E.P. Ilyin interprets motivation as a psychological foundation for learning [6]. This issue includes students' emotional stability, which reduces the negative impact of strong emotional influence and prevents the development of stress among students. Due to this, emotional stability is one of the most important factors of reliability, efficiency, and success in learning activity. On the other hand, management theory advocates treat motivation as a process of encouragement, stimulation of oneself or others towards a deliberate mode of behaviour or the performance of certain actions aimed at achieving a specific goal. Besides, motivation acts as readiness to make every possible effort to achieve goals to meet definite individual needs.

Among foreign studies devoted to learning motivation, special attention is paid to the work of the German psychologist, Professor Reinhard Pekrun from the University of Munich, the author of the control-value theory of achievement emotions.

The following thesis underlies this theory: the analysis of the control and significance of emotions is central to the emergence of achievement emotions, among which, on the one hand, it is possible to distinguish emotions associated with carrying out the activities (pleasure, frustration, boredom, experienced in the learning process itself), on the other hand, emotions are associated with the consequences, results of activities (joy, hope, pride, anxiety, hopelessness, shame, anger) [7].
A special interest is given to the research conducted by R. Pekrun together with A. Elliot and M. Maier on students [8]. It was found out that the achievement goals such as mastery, and the desire to demonstrate a result or avoid this demonstration - determine and predict various achievement emotions: pleasure, boredom, anger, hope, pride, anxiety, hopelessness, shame. In their turn, achievement emotions predict the achievement of results. Seven of the eight focal emotions appear between achievement goals and achieving results. It is noted that the findings are reliable when considering gender factors, social desirability, positive and negative emotionality and learning abilities.

To sum up, it should be stated that the problem of learning activity motivation has covered a long way of development. Academic motivation has been repeatedly analysed by various scientific schools and from different positions. Modern scientists agree that learning activity motivation is a complex structural issue, a source of activity and at the same time, a system of activity stimuli.

Russian methodologists have identified several factors that determine the development of motivation for the learning activity of students (A.N. Leontyev [9], G. Rosenfeld [10], A.K. Markova [11], N.F. Talyzina [12]).

Research results demonstrate that it is motivation that is the basis of practically all forms of purposeful activity of a person which he/she adopts in the process of individual learning and gaining experience. They unite all types of a person's needs determined by the social environment impact including political, moral and aesthetic ideals, his/her desire for cognition of the world, etc. People with the marked need for achievement prefer and are better at solving problems of moderate difficulty, they take responsibility for the results of their activity, seek for feedback on its success and try to invent or master new and more efficient ways of fulfilment of different tasks.

Teaching problems arise with every subject including foreign language learning [13].

The content and forms of education are considered to be the factors contributing to the development of learning activity motivation. Modern trends in the use of ICT allow us to revise some approaches to future specialists' training [14], [15]. Modern linguo-didactics presents a number of techniques and methods for the formation and improvement of communicative competence, meanwhile, due to the availability of digital materials and network technologies, the use of authentic video and audio materials becomes relevant.

Among the factors that determine the usefulness of video materials application in the learning process and form students' motivation, experts highlight the possibility of a more active creative activity of a teacher.

Methodologists distinguish four main types of video materials that can be used in teaching foreign languages for professional communication. Firstly, these are specially developed educational videos included in the set of modern teaching materials (TM). The major advantage of these 
videos is that they are designed for learners in accordance with the level of language proficiency. However, there are practically no video materials that meet the needs of students who need a foreign language in certain areas of professional communication.

Secondly, these are videos that are easy to buy or rent. These are feature films, documentaries, educational programmes, etc.

Thirdly, these are programmes recorded directly from television, which are called off-air programmes. They include news programmes, documentaries, or scientific and educational programmes. In that case, it is important to choose programmes taking into account their duration and the language level of students.

While Selecting suitable material for students, J. Lonergan singled out the fourth category of educational video materials, namely videos filmed independently by students and the teacher [16]. There are several ways to use a video camera in the process of foreign language learning. First, it can be used to capture the speech activity of a teacher or students and use this material for feedback. Second, a video camera can be used to record material and then use it for educational purposes. Then, the actual use of video materials in the classroom will be similar to the use of off-air programmes, the only difference is that all aspects of the material can be controlled by the teacher. The third and probably the most exciting opportunity is the use of video cameras by the students. According to J. Lonergan and M. Allan, the film making process is teamwork, and the planning and production processes involve a number of discussions (i.e. speech product) in addition to the language being studied used in the film itself $[16,17]$. In addition, the process of making a film includes an emotional component.

Thus, the present research is aimed at analysing the views of Russian undergraduate students on the role of video materials in the process of forming and maintaining motivation to learn the language for specific purposes (LSP). There are some gaps in the pattern of the given topic in the theory of methodology that can be filled with the help of the present research.

\section{Methodology}

\subsection{Methods of Research}

To identify the factors that influence the development of students' motivation when working with authentic video materials, a set of methods was employed. With the help of the method of theoretical literature analysis, the goal and hypothesis of the study were formulated. Its tasks were also stated. Then factors which influence the level of students' motivation in the process of learning a foreign language using authentic materials were selected. In the course of this research, empirical methods of the survey were employed (questionnaire method) and assessment of respondents' attitude towards the research was made using Likert scale which helped to get quantitative assessments.

To identify the factors that influence the development of students' motivation when working with authentic video materials, a set of methods was employed. With the help of the method of theoretical literature analysis, the goal and hypothesis of the study were formulated. Its tasks were also stated. Then factors which influence the level of students' motivation in the process of learning a foreign language using authentic materials were selected. In the course of this research, empirical methods of the survey were employed (questionnaire method) and assessment of respondents' attitude towards the research was made using Likert scale which helped to get quantitative assessments.

Only students took part in the survey (sample number is 67 people). Students were asked to rank the factors mentioned below that can increase their interest in learning foreign languages in the classroom at the university. The respondents' answers were presented in the form of a four-point scale, where 3 meant very important, 2 meant partially important, 1 meant still less important and 0 meant not important at all.

A survey was also aimed at identifying the needs of students, which they can satisfy by studying a foreign language. To analyse the data, the method of categorization was used (Categorizing method). Students' answers to the question about the aim of foreign language learning when they freely worded their answers were studied. After the analysis, 11 categories and 6 subcategories were singled out for further statistical processing. The survey results are given below in Table 1 and Table 3 respectively. The results of the survey are presented below.

During one academic term, experimental learning was conducted, during which it was monitored how various types of work with video materials can increase the motivation of foreign language learning. During the research, special attention was paid to the factors that increase the interest in foreign language learning, identified by the students' survey.

\subsection{Study Group}

The present research was conducted among the 3rd year students at Moscow Region State University (31 people) and students of RUDN University, the faculty of Economics (36 people). Participation in the study was voluntary.

Students learn French and German: MRSU - 10 hours a week, RUDN - 10 hours a week. For MRSU students, a foreign language is the main subject, because they are future foreign language teachers. The language proficiency level of these students in the third year is B2-C1. MRSU students study foreign languages (in this case, we are talking about the study of French as the first foreign language) using a great deal of information on the social, cultural, political life of native speakers, i.e. in close 
connection with the world of the languages being studied. Here we see a comprehensive study of the country: its population and religion, history and ethnography, economy and politics, science and culture, language and literature, traditions, and values. The lecturers of the Faculty of Romance-Germanic Languages of Moscow Region State University teach the students in accordance with the new model of training specialists in international and intercultural communication.

RUDN University students study in-depth LSP as part of extracurricular education [18]. They begin to study the generally spoken language, then the language of business communication and LSP. The level of language proficiency of RUDN University students (3rd-year students) is B1-B2. As a result of the learning process, aimed mainly at learning LSP, students quickly reach the level that allows them to read and translate specialised texts, understand the messages of the audio-visual media. Students are able to hold conversations on profession-oriented topics, as well as on general ones.

Due to the relatively small number of hours and high requirements, language learning requires students to have demands in a high level of motivation and good organization of learning activities from students.

\subsection{Hypothesis}

To increase the motivation of students and improve the quality of foreign language teaching, it is necessary to identify the factors that influence the formation of students' motivation.

The aim of our research is to distinguish the types of motivation that are especially significant for bachelor students and how authentic video materials contribute to the development of these types of motivation.

Based on the analysis of the experience of Russian and foreign methodologists, the authors supposed that the most important factors encouraging the motivation of learning activity are:

- $\quad$ pedagogical support of the learning process, including the development of methodological recommendations for classroom and independent work of students;

- the implementation of various pedagogical technologies that arouse interest among students in learning foreign languages;

- $\quad$ the creation of a favourable educational environment;

- $\quad$ properly developed curriculum;

- the opportunity to plan learning activities independently;

- the relevance of syllabus (the relevance of the selected learning material);

- the assessment of students, the existence of feedback.

The use of various techniques for working with video materials, taking into consideration the factors of motivation increase that are significant for students, will have a positive effect on the growth of the cognitive interest among students.

\section{Results}

The research was carried out during one term and included several stages. Three seminar groups of MPSU students and three seminar groups of RUDN University students took part in the research. Two lecturers worked with each group. Thus, twelve lecturers were involved.

\subsection{Identification of the Learners' Needs}

Like any kind of activity, learning activity is meant to meet the specific needs of students. The first stage of our research identified the most important needs of students. The students were asked to answer in writing the question What is the purpose of studying foreign languages?" The summarised results are presented in Table 1.

Table 1. Identification of students' needs

\begin{tabular}{|c|c|c|}
\hline $\begin{array}{c}\text { I study a foreign language } \\
\text { because... }\end{array}$ & $\begin{array}{c}\text { MRSU, } \\
\%\end{array}$ & $\begin{array}{c}\text { RUDN } \\
\text { UNIVERSITY, } \\
\%\end{array}$ \\
\hline $\begin{array}{c}\text { Interesting subject / interest in } \\
\text { foreign languages }\end{array}$ & 98 & 87 \\
\hline $\begin{array}{c}\text { Promotion opportunities / sideline } \\
\text { opportunity }\end{array}$ & 99 & 68 \\
\hline $\begin{array}{c}\text { Possibility of getting a degree } \\
\text { abroad }\end{array}$ & 39 & 27 \\
\hline $\begin{array}{c}\text { Travel possibilities } \\
\text { Facilitation of socialization, } \\
\text { paking friends/finding foreign }\end{array}$ & 65 & 57 \\
\hline $\begin{array}{c}\text { Possibility of understanding } \\
\text { professional literature }\end{array}$ & 59 & 63 \\
\hline $\begin{array}{c}\text { Possibility of studying foreign } \\
\text { culture / reading fine literature }\end{array}$ & 89 & 42 \\
\hline $\begin{array}{c}\text { It is easy / possibility of being } \\
\text { successful in learning }\end{array}$ & 61 & 7 \\
\hline $\begin{array}{c}\text { Parents' desire } \\
\text { language }\end{array}$ & 8 & 30 \\
\hline $\begin{array}{c}\text { It is prestigious / every intelligent } \\
\text { person should know a foreign }\end{array}$ & 95 & 91 \\
\hline
\end{tabular}

Among the given answers, it is possible to distinguish the communication need, the cognitive need, the need for self- esteem, the need for public recognition, and the need for self-expression.

As it can be seen from the table, cognitive interest is dominant among students at both universities. MSRU students associate their professional activities with foreign languages (teaching foreign languages, tutoring and translation). RUDN University students consider the knowledge of foreign languages as a professional advantage in case they find a job in an international company. $45 \%$ of RUDN University students and $39 \%$ of MRSU students plan to do the postgraduate course abroad.

Learning foreign languages to be able to travel is not a 
leading need for students as it is not necessary to know the language at a high level to do this, besides modern gadgets help to overcome the language barrier. The ability to communicate with friends (a communicative need) is important for half of the respondents. The expansion of economic, cultural and sports (2018 FIFA World Cup Russia) connections provides many opportunities for communication.

Many students associate the need for professional self-improvement and development with knowledge of foreign languages. This is especially relevant for future economists and managers. For future teachers of a foreign language, the opportunity to get acquainted with the achievements in culture in the original language is of greater interest.

Language learning urged by parents' desire is not a significant reason for the students' choice) at both universities. It also refers to getting a degree. These indicators show that students had developed a cognitive interest and the knowledge gained is valuable.

The need to feel successful while studying is an important emotional component of the learning process. Students often face negative motivation, fear of punishment, fear of being worse than others. Teamwork, clear recommendations from lecturers can help overcome these fears.

Prestige is one of the leading motives for learning a foreign language. University students represent the country's future elite. It is important for them to be associated with the intellectual society, and one of the signs of an intelligent person is mastery of a foreign language.

Thus, the analysis of the basic needs of students made it possible to identify the most significant motives of the learning activity of students. These include the social motive, the achievement motive, the motive for acquiring the necessary knowledge (cognitive motive), the motive for self-determination, the motive for achieving success in the profession, the motive for creative development.

\subsection{Students' Survey}

To identify the importance for students of factors influencing the development of motivation, a survey was conducted, the results of which are presented in Table 2.

According to the results of the survey, for senior undergraduate students, the quality of the syllabus acquires the greatest value. The proposed materials should be relevant and reflect the latest achievements in a particular subject area. While studying foreign languages, this requirement can be satisfied, but some effort on the part of lecturers to search and select learning material is needed.

For senior students, when there is an opportunity to choose specialised courses or individual seminars, and to engage in scientific activities in the process of learning, the prospect of planning their educational activities independently plays an increasingly crucial role. Within the framework of the concept of lifelong learning, this competence is the most important one for future specialists.

Table 2. Factors affecting student motivation

\begin{tabular}{|c|c|}
\hline Factor & $\begin{array}{c}\text { Average } \\
\text { grade }\end{array}$ \\
\hline Pedagogical support of the learning process & 2,6 \\
\hline Implementation of various pedagogical technologies & 2,7 \\
\hline Creation of a favourable psychological environment & 2,3 \\
\hline $\begin{array}{c}\text { The possibility of planning learning activities } \\
\text { independently }\end{array}$ & 2,8 \\
\hline The relevance of the syllabus & 2,9 \\
\hline $\begin{array}{c}\text { Adequate assessment of students, the existence of } \\
\text { feedback }\end{array}$ & 2,4 \\
\hline Properly developed curriculum & 2,1 \\
\hline
\end{tabular}

Implementation of new, innovative pedagogical technologies and psychological and pedagogical maintenance of the learning process is equally important for the formation of motivation.

The creation of a favourable psychological environment helps to develop motivation, but unlike first-year students, it is not a leading factor. This statement is also relevant for the following factor "Adequate assessment of students, the existence of feedback".

A properly developed curriculum does not significantly affect the formation of motivation. This factor was important at the stage of choosing the direction of study. Within the learning process, the actual content of the discipline and the relevance of learning materials play a significant role.

\subsection{Working with Authentic Video Materials}

While teaching LSP, lecturers actively used authentic video materials in the classroom (documentaries, programmes with political and economic news, interviews with politicians on topical issues of the modern world).

The use of authentic materials requires $t$ careful material selection and the lecturer's preparation. Before watching the video material, the tasks performed by the students remove the language difficulties of perceiving the video text and understanding its meaning. Tasks offered by the lecturer after watching the video should generate and maintain students' interest in discussing the video. If any of the students have already seen this video, then such students can discuss specific details, problems raised in the video, or help other students understand its content.

The lecturers used various methods and techniques for working with video materials for academic purposes. The choice depended on the needs of the students, on the goals and objectives of the learning process, as well as on the video material itself. Among the techniques, we can distinguish, for example, the sequence of viewing the episodes - which means that teaching with the help of video is intended not only for students with a high level of language proficiency but can be useful in the process of teaching students with an intermediate level of language 
proficiency. And even students with a lower level of proficiency can also successfully work with video materials, but only when the full-length video is divided into 10-minute parts. Together with the pre-demonstration and post-demonstration stages, one 10-minute episode can provide enough material for a full 90-minute session. Replay was also widely used. This technique is useful if, after watching an episode of a movie for the first time, you ask students to do one of the after-watching assignments and prepare them for the next assignment, which they will do during or after the second watching. Then there is an active viewing phase: it is important for students to realise that they should be active while watching, not just having fun. The lecturers prepared a series of stimulating (motivational) assignments that introduced students to several stories in the video, such as setting, situations, culture, history, and language. It was important to inform the students before watching what they were required to do while watching, this helped them to focus on certain plots of the video. Groups with different levels of language proficiency used different strategies for viewing and understanding the video material: general understanding, detailed understanding, search for the necessary information, full understanding. The efficiency of the video lesson depends on how the students react to watching the video. The lecturers proposed special techniques for working with video material, namely:

- Watching video without sound: students and the lecturer discuss what they see and try to guess what the characters are speaking about. Once all the assumptions have been made, students review the video again and check the correctness of their guesses.

- $\quad$ Listening to the video without a picture: this changes the previous procedure to the exact opposite. While students listen to the video, they try to guess where the characters are, how they look, what is happening, etc. Once all the assumptions are made, the students listen again, but this time they also watch the video.

- $\quad$ Picture freeze: the lecturer pauses the video and asks the students to guess what will happen next. Will they be able to guess? The group is divided into two subgroups: the first subgroup sits facing the screen, the second subgroup sits with its back to it. The first subgroup describes to the second subgroup what is happening on the screen. There are many other ways to work with video materials. This type of work provides great opportunities for realising the lecturer's creative potential.

\subsection{Students' Work on Film Making}

Within the framework of the research, students were asked to make their own film. They chose the theme of the film. As a result, the students shot four films of 8-12 minutes each on the topics "My University" (MSRU, RUDN University) (Tasks of the Student Olympiad organised by the German Cultural Centre Goethe Institute), "Job interview" (RUDN University), "My future profession of a French teacher (within the framework of the competition announced in 2019 by the Government of France) "(MSRU).

The film making process included several stages:

1. Preparatory stage. At this stage, students organised creative groups on a voluntary basis and chose the theme of the project.

2. Planning stage. Identification of the purpose of work, studying the assessment criteria, determination of the types of work, and appointment of the tresponsible persons. Implementation stage. The discussion and writing of a script, selection of language material, rehearsals, shooting, film editing.

3. Presentation of the finished film.

4. Discussion, assessment in accordance with the criteria.

\section{Reflection.}

This type of work promotes the development of thinking and shapes up social and communicative competencies, such as the ability to lead a discussion, defend their point of view, find a compromise, and evolve leadership qualities. Cognitive and affective competencies are formed:

- $\quad$ to classify, research, analyse;

- $\quad$ to persuade, argue, propose, hypothesise, justify recommend;

- $\quad$ to be able to deal with criticism;

- to work as a member of a team in unfamiliar situations;

- $\quad$ to defend their position in front of others;

- $\quad$ (to) be the team leader;

- $\quad$ to sum up.

Ultimately, the use of video materials created by students in the learning process, which, along with communicative and linguistic competencies, also develops the so-called key competencies, prepares students for future professional activity.

In order to understand how film making influenced the development of students' motivation for foreign language learning the was carried out. The students answered the question "What did you especially like during film making?” The results are given in Table 3.

Table 3. Factors affecting students' motivation during film making

\begin{tabular}{|c|c|}
\hline What did you especially like during film making? & No./\% \\
\hline The opportunity to reveal my strong suit & $60 / 89,5$ \\
\hline The opportunity to work in a team & $62 / 92.5$ \\
\hline $\begin{array}{c}\text { Interesting and creative work } \\
\text { Successful solution of complicated problems/result } \\
\text { achievement }\end{array}$ & $65 / 97$ \\
\hline $\begin{array}{c}\text { The opportunity to develop new skills, acquire new } \\
\text { knowledge }\end{array}$ & $62 / 92,5$ \\
\hline Important for the future profession & $39 / 58$ \\
\hline
\end{tabular}

The survey data confirmed the results given in Table 1. 
The main motives were the motives of creative development (97\%), social motive (92.5\%) and cognitive motive (92.5\%). The achievement motive is also important (89.5\% and $85.5 \%)$. The motive of profession success achievements was not leading (58\%).

\section{Discussion}

The findings of the present study confirm the hypothesis put forward by the authors that the most significant factors for the formation and development of motivation for learning activity are pedagogical support of the learning process, the creation of a favourable psychological environment in the classroom, the opportunity to plan learning activity independently, etc. The selection of these factors was based on the research of Russian and foreign scientists. All identified factors are significant for students. The most important ones are the formulation of pedagogical recommendations for the work of students, implementation of various pedagogical technologies, as well as the opportunity to plan learning activity independently.

It is worth pointing out that the creation of a positive emotional environment can increase students' motivation. On the contrary, negative emotions can reduce students' motivation. A psychologically comfortable academic environment affects the emotional behaviour of people in a group situation and therefore, the work of the whole group [19]. The emotions of others affect the emotional state of an individual. One of the provisions of the self-efficacy theory proposed by Albert Bandura is that the process of modelling success situations is based on relationships with others. Emotional relationships with people who are significant for the student (the lecturer, groupmates) positively affect the degree of self-confidence and success [20].

Such a factor as the opportunity to plan learning activity independently plays an essential role in the formation of students' motivation. This conclusion can be found in the treatises of S.B. Merriam and L.L. Bierema (2014) who identify the importance of «Self-Directed Learning» in adult learning [21].

In the course of our work, certain differences from the research results of foreign methodologists were revealed. Modern European scientists A.A. Kahler, B. Morgan and G.E. Holmes emphasise the importance of a proper curriculum that meets certain standards. All educational programmes in Russia are developed in accordance with the new Federal State Standards. Recently, employers' representatives have been involved in the development of training programmes and learning materials, which makes these programmes effective and relevant. However, this factor is not leading for students in the development of motivation.

In addition to identifying factors affecting the formation of motivation, the authors had a goal to determine how the implementation of various techniques for working with video materials contributes to the development of certain types of motivation.

Based on the results of experiential learning, we can conclude that one of the main advantages of using authentic materials taken from the subject area of students is that they change the "balance of power" within the classroom. According to M.K. Phillips and C.C. Shettlesworth, "the lecturer is no longer the undisputed authority in the discussion and should recognise the competence of students in the professional field" [22]. In this case, students are engaged in the process of helping the lecturer in understanding profession-oriented material. This encourages the creation of a psychologically comfortable academic environment. Students will definitely experience positive emotions when they understand the material aimed at native speakers. Students note that LSP is not inaccessible for them, and this can encourage further use of authentic materials in the classroom. Students seem to be more interested when they observe the use of the foreign language being studied in real situations of professional communication. It motivates more than any other factor. Properly prepared video material can motivate students to speak and participate, for example, in a role-play or discussion.

\section{Conclusions}

Based on the present research, it can be concluded that lecturers should use a variety of forms of work to generate and develop students' motivation. For the measures taken to be effective (efficient), it is necessary at the beginning and during the learning process to monitor the factors affecting the development of motivation. In modern conditions, while digital technologies are becoming increasingly important, doing various kinds of tasks when working with video materials in the classroom is highly topical. The experience of organising shooting of a video as project work contributes not only to the development of students' motivation but also forms their communicative and social competencies.

\section{Acknowledgements}

The reported study was funded by RFBR, project number 19-012-00515.

\section{REFERENCES}

[1] C. Kobylinski, M. A. Heinz. Qualitative Analysis of Korean Students' Awareness of Motivational Macro Strategies, 
Journal of Education and Development, Vol. 2, No. 3, 1-7, 2018.

[2] B. P. Dhakal. Virtual Learning Environment (VLE) in Mathematics Education, Education Journal, Vol. 5, No. 6, 126-135, 2016.

[3] H. Kurniawan, Budiyono, Sajidan, Siswandari. Concrete-Pictorial-Abstract Approach on Student's Motivation and Problem Solving Performance in Algebra, Universal Journal of Educational Research, Vol. 8, No. 7, 3204-3212, 2020

[4] D. Wang, M. N. M. Khambari. An AR-based Gamified English Course in Vocational College through Interest-driven Approach, Universal Journal of Educational Research, Vol. 8, No. 1A, 132-137, 2020.

[5] M. E. Adebiyi, Y. Al-Hassan, C. Hansbourgh, C. Edginton. Values Attached to Educational Goals, Study Processes, and Educational Motivation, Journal of Education and Development, Vol. 1, No. 1, 48-57, 2017.

[6] E. P. Ilyin. Motivation and motives, Spb, St. Petersburg, 2002.

[7] R. Pekrun. The Control-Value Theory of Achievement Emotions: Assumptions, Corollaries, and Implications for Educational Research and Practice, Educational Psychology Review, Vol. 18, No. 4, 315-341, 2006.

[8] R. Pekrun, A. J. Elliot, M. A. Maier. Achievement Goals and Achievement Emotions: Testing a Model of Their Joint Relations with Academic Performance, Journal of Educational Psychology, Vol. 101, No. 1, 115-135, 2009.

[9] A. N. Leontyev. Activity. Consciousness. Personality, Politizdat, Moscow, 1975.

[10] G. Rosenfeld. Theorie und Praxin der Lermotivation Rosenfeld, Berlin, 1973.

[11] A. K. Markova. Academic motivation, and its development among schoolchildren, Pedagogy, Moscow, 1983.

[12] N. F. Talyzina. Formation of cognitive activity among students, Znaniye, Moscow, 1983.

[13] C. Altıner. Preparatory School Students' English Language Learning Motivation: A Sample from Turkey, Universal Journal of Educational Research, Vol. 6, No. 8, 1729-1737, 2018.

[14] E. Malyuga. Exploiting the potential of ICT: assessment of students' knowledge, Proceedings of SGEM2016 conference, Bulgaria, Albena, Book 1, Vol. 3, 319-325, 2016.

[15] E. Malyuga, A. Shvets, I. Tikhomirov. Computer-Based Analysis of Business Communication Language, SAI Computing Conference 2016. July 13-15, 2016, London, UK, 229-232.

[16] J. Lonergan. Video in Language Teaching, Cambridge University Press, Cambridge, 1984.

[17] M. Allan. Teaching English with Video, Longman, London, 1991.

[18] N. V. Polyakova, N. A. Skitina, V. P. Shabanova. Teaching idiomatic speech at foreign language classes, EDU-LEARN17 Proceedings, 9002-9005, 2017.

[19] M. V. Lyashenko. Motivation of learning activities: basic nations and issues, SUSU Bulletin, Edition "Education. Pedagogical Sciences”, Vol. 11, No. 1, 53-73, 2019.

[20] A. Bandura. Self-efficacy: The exercise of contro, Freeman, New York, 1997.

[21] S. B. Merriam, L. L. Bierema. Adult Learning: Linking Theory and Practice, 1st Edition, Yossey-Bass A Wiley Brand, San Francisco, 2014.

[22] M. K. Phillips, C. C. Shettlesworth. How to Arm Your Students: A Consideration of Two Approaches to Providing Materials for ESP, 1978. 